\title{
TENSILE TESTS OF TYPE 305 STAINLESS STEEL MINE SWEEPING WIRE ROPE
}

\section{T. Robert Shives} Samuel R. Low, III

U.S. DEPARTMENT OF COMMERCE National insttute of Standards and Tochnolody Motallurdy Division

Gelthersburs, MD 20899

U.S. DEPARTMENT OF COMMERCE Robert A. Mosbecher, Secretary MATRONAL IMSTITUTE OF STANDARDS AND TECHNOLOOY

Raymond a Kammor, Actins Director 
NATIONAL INSTITUTE OF STANDARDS \&

TECHNOLOGY

Research Information Center

Gaithersburg, MD 20899 


\section{TENSILE TESTS OF} TYPE 305

STAINLESS STEEL MINE SWEEPING WIRE ROPE

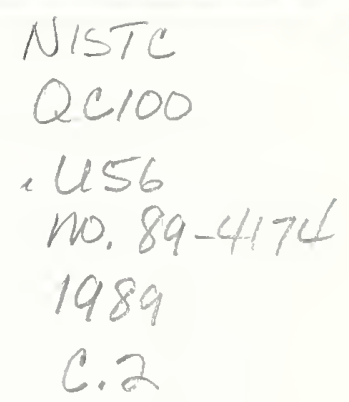

T. Robert Shives

Samuel R. Low, III

U.S. DEPARTMENT OF COMMERCE National Institute of Standards and Technology

Metallurgy Division

Gaithersburg, MD 20899

Sponsored by

Naval Coastal Systems Center

U.S. Navy

Department of Defense

Panama City, Florida 32407

October 1989



U.S. DEPARTMENT OF COMMERCE Robert A. Mosbacher, Secretary NATIONAL INSTIUUTE OF STANDARDS AND TECHNOLOGY

Raymond G. Kammer, Acting Director 



\section{INTRODUCTION}

The tensile tests described in this report were performed by the Metallurgy Division of the National Institute of Standards and Technology (NIST) at the request of the Naval Coastal, Systems Center, Panama City, Florida.

The Naval Coastal Systems Center submitted to NIST approximately 360 feet of each of two different AISI 305 stainless steel wire ropes for testing. Both wire ropes were nominally $5 / 8$ inch in diameter. One was stated as having a 6 $\times 19$ configuration and the other a $7 \times 7$ configuration. The first number in such a designation indicates the number of strands in the wire rope and the second number indicates how many wires there are per strand ${ }^{1}$. For example, the wire rope with a $6 \times 19$ configuration consists of six strands of 19 wires each. As shown later, the wire rope stated to have a $7 \times 7$ configuration actually had a $6 \times 7$ configuration with an independent wire rope core $(\text { IWRC })^{2}$. The core is one of the three basic parts of a wire rope. The other two are the wires and the strands. The core is the foundation upon which the wire rope is constructed. It must provide adequate support for the strands when the wire rope is in service. The core may be comprised of steel or fiber. In the case of both of the submitted wire rope samples, the core consisted of an independent wire rope.

\section{PURPOSE}

It was requested by the Naval Coastal systems Center that NIST determine the tensile strength of each of the two wire rope samples.

\section{CHARACTERIZATION OF THE WIRE ROPE SAMPLES}

Prior to determining the tensile strength of the wire rope samples, some preliminary characterization was performed in order to verify that the wire ropes were as stated.

\subsection{Metallographic Examination}

A cross section from each of the two wire rope samples was prepared in a metallographic mount and examined to confirm the configuration. Photomicrographs of the wire ropes stated to have a $7 \times 7$ configuration and a $6 \times 19$ configuration are shown in figures 1 and 2 , respectively. Both wire ropes have an independent wire rope core as stated above. The $6 \times 19$ wire rope is configured as stated. The wire rope stated to have a 7 x 7 configuration actually has a $6 \times 7$ configuration with an independent wire rope core. The independent wire rope core can be seen in figure 2 .

Representative etched fields of individual wires from each of the two wire rope types are shown in figures 3 and 4 for the $6 \times 7$ and the $6 \times 19$ configurations, respectively. The microstructures appear to be normal for cold worked AISI 305 stainless steel ${ }^{3}$. The center wire of the independent wire rope core of the $6 \times 7$ wire rope exhibited a somewhat finer grain size 
than the other wires. Microstructure representative of the center wire of the independent wire rope core is shown in figure 5.

A longitudinal specimen from each of the two wire rope configurations was examined metallographically. Several apparent lap seams were detected in the section of the $6 \times 19$ wire rope. They are similar in appearance to cracks. Two examples from wires from different strands are shown in figures 6 and 7 . In the plane of the specimen, the apparent lap seams measure 0.005 and 0.006 inch in figures 6 and 7, respectively. These lengths represent about 11 and 13 percent, respectively, of the diameter of the wire. No lap seams were found in the section of the $6 \times 7$ wire rope.

\subsection{Brooming}

Because of the apparent misnaming of the $6 \times 7$ wire rope, a small length of this sample was broomed ${ }^{4}$ to determine the twist direction of each strand of wires and to confirm that there was indeed an independent wire rope core. Brooming consists of spreading the strands apart at the end of a length of wire rope. A photograph of the broomed end is shown in figure 8 . The straight, untwisted independent wire rope core can be seen in the center.

\subsection{Hardness Measurements}

Knoop microhardness measurements at a load of 1000 grams force were made on representative wire from the cross sections of both wire rope samples that are shown in figures 1 and 2. Three measurements were made on each of four wires from the $6 \times 7$ specimen. Two measurements were made on each six wires from the $6 \times 19$ specimen. The average results of the Knoop hardness measurements and the approximate Rockwell C (HRC) equivalent values for each specimen are given in Table 1.

\subsection{Chemical Analysis}

It was confirmed by the NIST Center for Analytical Chemistry that the chemical composition of both wire rope samples corresponded to that specified for AISI 305 stainless steel in the 9 th edition of the Metals Handbooks. The specified composition is as follows: carbon - $.128 \mathrm{max}$, manganese - 2.008 max, silicon - 1.008 max, chromium - 17.0-19.08, nickel - 10.5-13.08, phosphorus - 0.045 \& max, and sulfur $-0.03 \% \max$.

\section{TENSILE TESTING}

\subsection{Specimen Preparation}

Four specimens of each the $6 \times 7$ and the $6 \times 19$ wire ropes were prepared for testing to determine breaking strengths. Terminals with closed epoxy resin filled type sockets were placed on each end of each cable sample by a commercial cable company in accordance with NIST instructions. The Wire Rope User's Manual, Second Edition (1981), published by the American Iron and Steel Institute, requires a minimum length of 36 inches between sockets for tensile specimens for wire rope with diameters of from $1 / 8$ through 3 inches ${ }^{6}$. There were 36 inches of unconstrained wire rope between the sockets. This length 
was the minimum allowed by the Wire Rope. User's Manual. A photograph of one of the terminals is shown in figure 9.

\subsection{Tensile Tests}

Each of the specimens was tested in tension with a Satec Systems vertical tensile testing machine having a capacity of $25000 \mathrm{~kg}(55000 \mathrm{lb})$. Even though the shortest allowable specimens were used, the maximun opening between the upper and lower cross heads of the testing machine was insufficient to accommodate the wire rope specimens. Therefore, a fixture was designed and built to effectively increase the working distance between cross heads. The specimens were attached to the machine for testing with a clevis/pin arrangement at both top and bottom. A typical specimen setup is shown in figure 10. Tests were run at a constant cross head speed of 0.2 inch per minute. Time vs cross head displacement data were recorded with a computer controlled data acquisition system at the rate of one data point every 2 seconds.

Three specimens of each wire rope configuration were tested until total separation of all the wires between the terminals had occurred. The fourth specimen of each configuration was tested until the fracture at maximum load had occurred. The maximum loads sustained by the specimens during testing are presented in the table 2. Load/displacement plots for all eight specimens are presented in figures 11 through 18. Photographs of the tested specimens are shown in figures 19 through 26.

Failure of the $6 \times 19$ wire rope samples generally initiated with one or a few individual wires fracturing. These fractures were audible and they produced small jogs in the load/displacement curves (figures 15 through 18). For instance, for specimen $6 \times 19-1$ (figure 15), the first two evident wire fractures occurred at loads of approximately 10000 and 18500 pounds. Essentially simultaneous fracture of several strands occurred at the maximum load sustained by the cable. At this point, the sustained load dropped to nearly zero, although the cross heads continued to move apart. Displacement from the point of the first application of load to first strand fracture ranged from 1.7 to 1.8 inches. After further cross head displacement of 0.1 to 0.2 inches, the remaining strands of cable began to sustain load again. The apparent reason for the load having dropped so drastically when the first strands fractured was that with the fractured strands no longer constraining them, the remaining strands were free to at least partially straighten, thereby becoming effectively longer than they had been. The maximum loads reached subsequently were lower than the initial maximum load because the effective cross sectional area of the wire rope had been reduced. Total displacement from the point of initial application of load to final fracture of the last strand for specimens $6 \times 19$ - 1 through $6 \times 19-3$ ranged from 4.7 to about 5 inches.

In the testing of the $6 \times 7$ specimens, there was no indication that failure initiated by the fracture of individual wires or a few wires (figures 11 through 14). The first indication of failure was the fracture of several strands. As in the $6 \times 19$ cable specimens, after initial failure, the load dropped to nearly zero before again increasing as the cross heads continued to separate. Displacement from the point of the first application of load to 
the point of the first application of load to initial strand fracture ranged from about 1.9 to 1.95 inches for the $6 \times 7$ specimens. Total displacement from the point of the first application of load to final fracture of the last strand for specimens $6 \times 7-1$ through $6 \times 7-3$ ranged from 4.05 to 4.40 inches.

\section{DISCUSSION AND CONCLUSIONS}

Both wire rope samples were verified to be composed of AISI 305 stainless steel as stated. The configurations of the two wire ropes are $6 \times 7$ and $6 \times$ 19, both having an independent wire rope core. The stated configurations of the samples when received at NIST were $7 \times 7$ and $6 \times 19$.

The average maximum tensile load supported by the $6 \times 19$ configured wire rope specimens before fracture was 33600 pounds, whereas the average maximum load supported by the $6 \times 7$ wire rope was 33150 pounds, or 450 pounds less. Military Specification MIL-W-18242B(SH) ${ }^{7}$ calls for a minimum breaking strength of 32000 pounds for 5/8 inch diameter AISI 305 stainless steel $6 \times 19$ and $7 \times$ 7 cable with an independent wire rope core. Even though the wire rope listed as being $7 \times 7$ appears to be $6 \times 7$, both wire ropes satisfy the tensile requirements of Mil-Spec MIL-W-18242.

The flaws detected in the $6 \times 19$ cable sample consisting of apparent lap seams are not uncommon in wire rope. Regardless of these flaws, the material had more than adequate tensile properties. Both hardness and microstructures are typical for cold worked AISI 305 stainless steel. 


\section{REFERENCES}

1. Wire Rope Users Manual, Second Edition, American Iron and Steel Institute, Washington, DC, 1981, chapter 3.

2. Ref. 1, chapter 2 .

3. Atlas of Microstructures of Industrial Alloys, Volume 7, Metals Handbook, 8 th Edition, American Society for Metals, Metals Park, OH, 1972, pp. 133136.

4. Ref. 1, p. 112 .

5. Properties and Selection: Stainless Steels, Tool Materials and SpecialPurpose Metals, Volume 3, Metals Handbook, 9 th Edition. American Society for Metals, Metals Park, OH, 1980, p. 5.

6. Ref. 1, p. 77 .

7. Wire Rope and Wire Rope Assemblies; Single Leg-Corrosion Resisting Steel, Minesweeping, Military Specification MIL-W-18242B(SH), 13 October 1987, p. 4. 
Table 1. Results of Hardness Measurements on Wire Rope Specimens.

Specimen Location

$6 \times 7$ Center wire, IWRC

$6 \times 7$ Outer wire, IWRC

$6 \times 7$ Center wire, outer strand

$6 \times 7$ Outer wire. outer strand

$6 \times 19$ Centex wire, center strand, IWRC

$6 \times 19$ Outer wire, center strand, IWRC

$6 \times 19$ Center wire, outer strand, IWRC

$6 \times 19$ Outer wire, outer strand, IWRC

$6 \times 19$ Outer wire, outer strand

$6 \times 19$ Intermediate wire, outer strand
Average $H_{1000}$ HRC Equivalent

421

43

398

40

400

41

385

39

437

44

460

46

454

46

415

42

420

43

439

44

a $\mathrm{HK}_{1000}=$ Knoop hardness at a load of 1000 grams force

b $H R C=$ Rockwell hardness, $C$ scale 
Table 2. Results of Tensile Tests of Wire Rope Specimens.

Specimen Number

$6 \times 7-1$

$6 \times 7-2$

$6 \times 7-3$

$6 \times 7-4$

Average $6 \times 7$

$6 \times 19=1$

$6 \times 19-2$

$6 \times 19-3$

$6 \times 19-4$
Maximum Load Sustained, Ibs ${ }^{\text {a }}$

33200

33200

33100

33100

33150

33800

33500

33800

33300

33600

Average $6 \times 19$

a Values rounded to the nearest 100 pounds. 


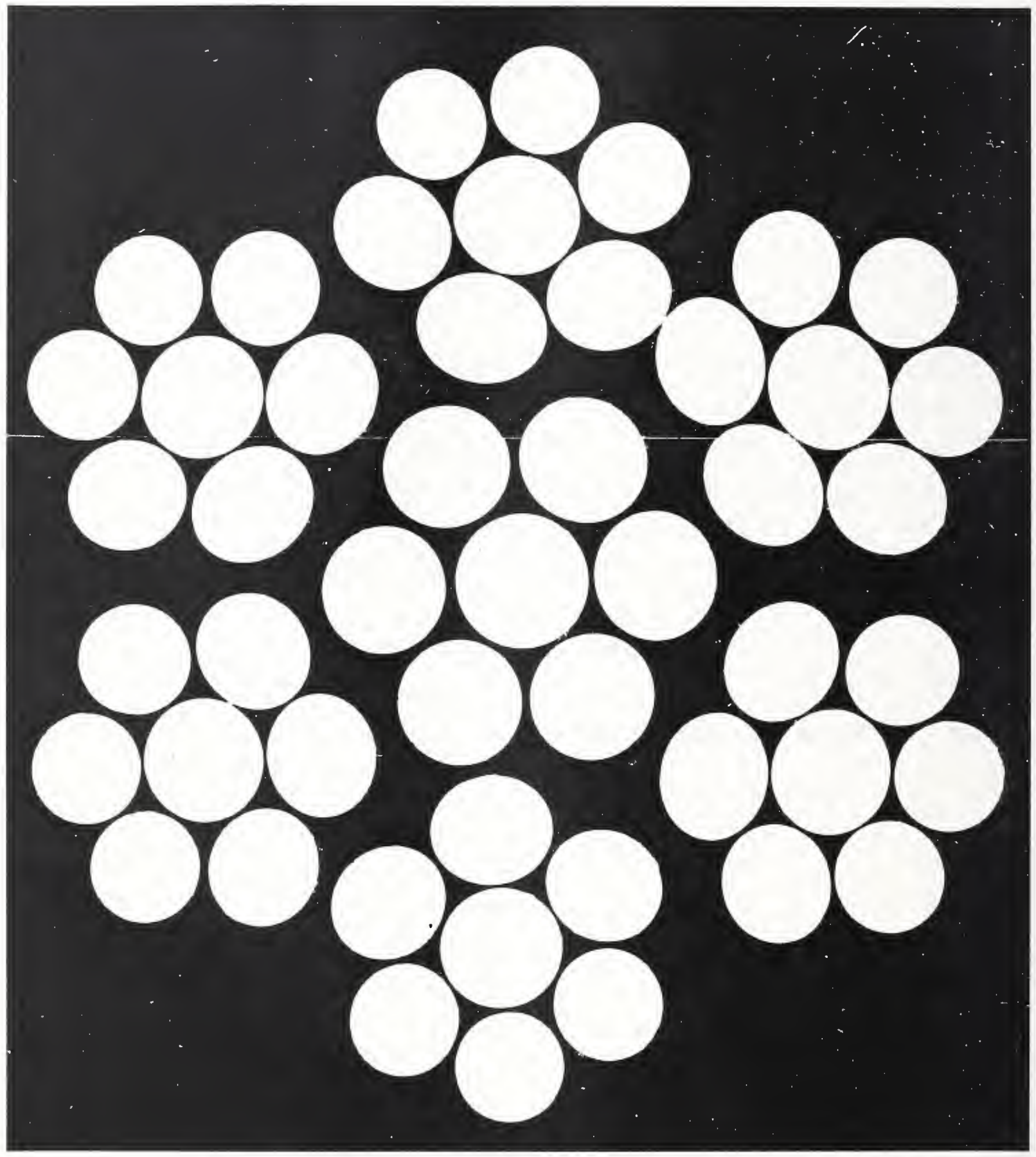

Figure 1. Polished cross section through the $6 \times 7$ wire rope. X 10 


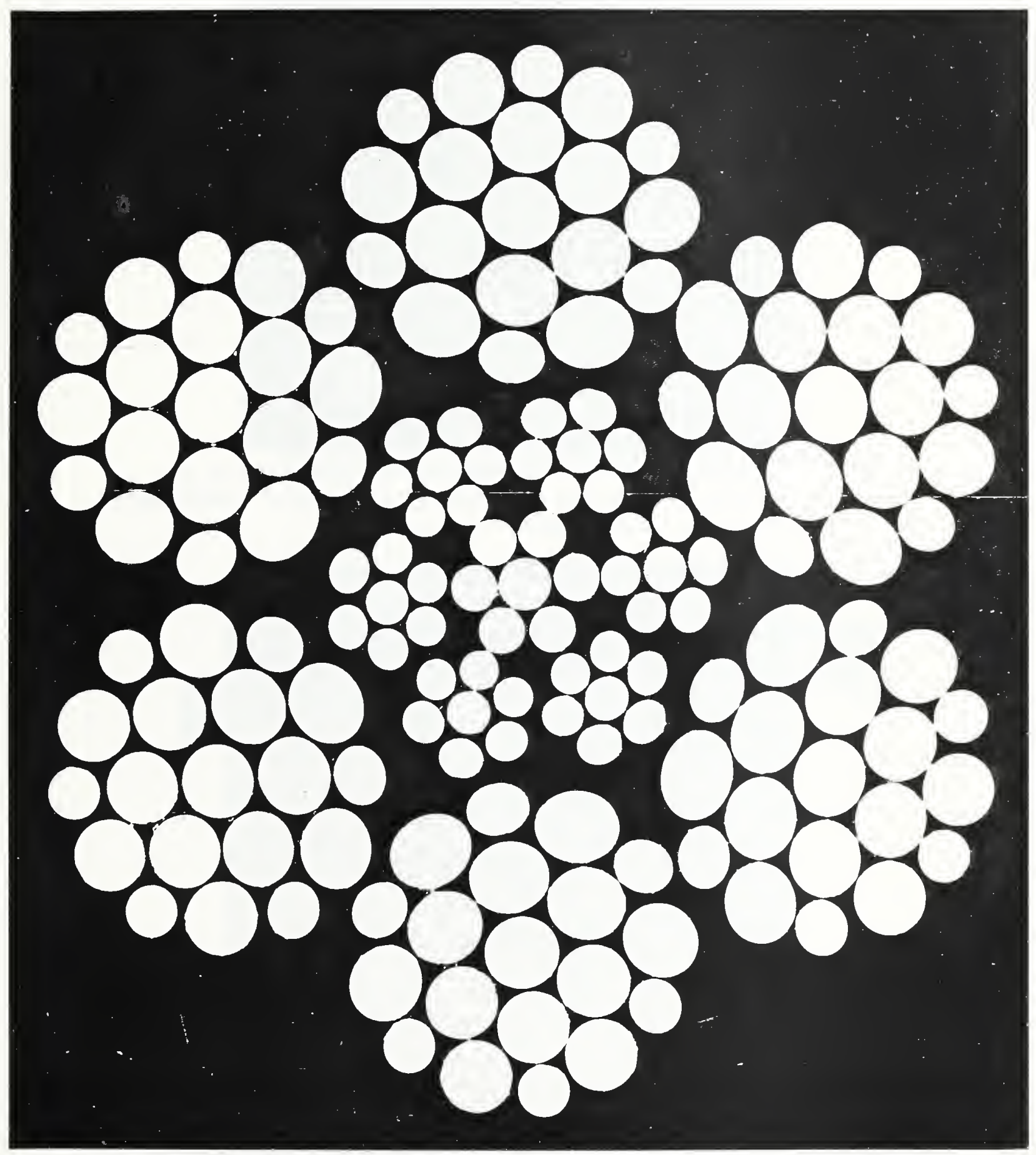

Figure 2. Polished cross section through the $6 \times 19$ wire rope. X 10 


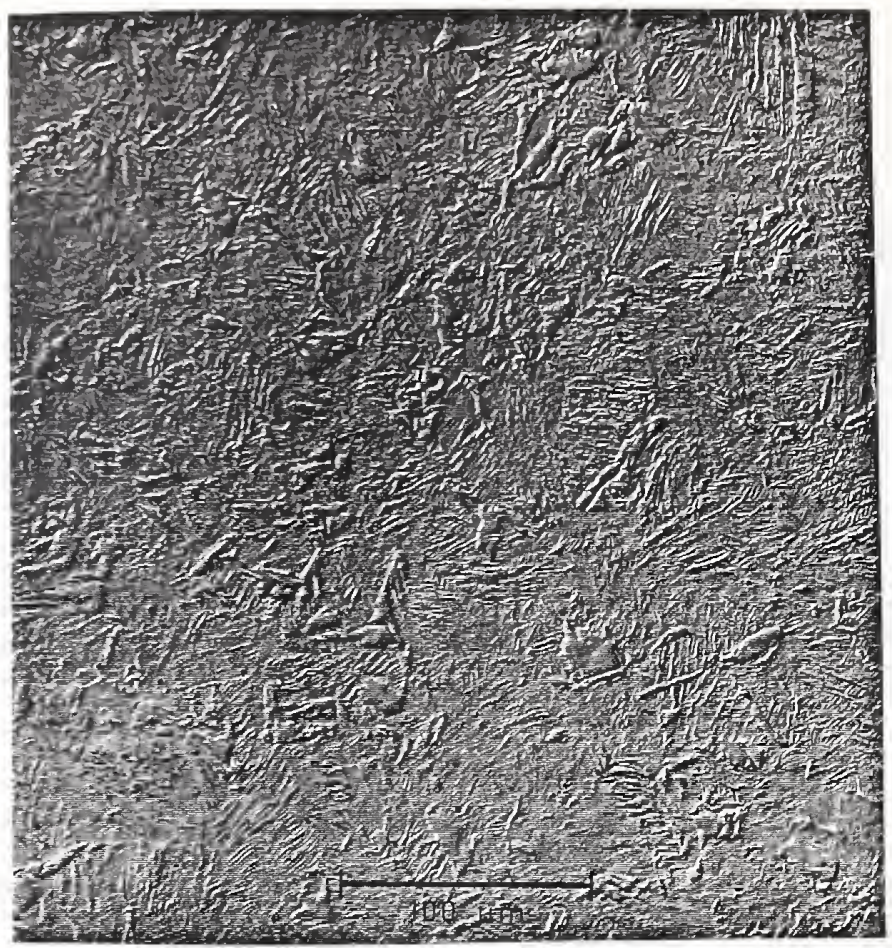

Figure 3. Representative microstructure of a wire from one of the outside strands of the $6 \times 7$ wire rope sample. Etchant: Glyceregia

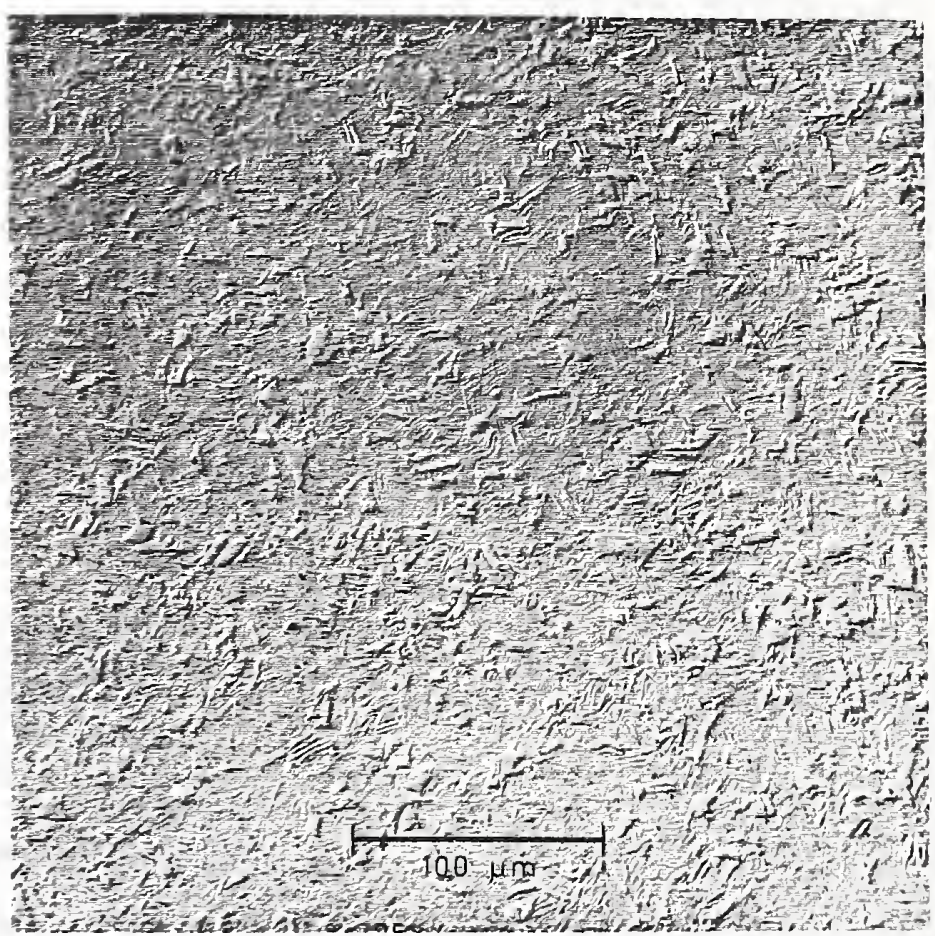

Figure 4. Representative microstructure of a wire from the $6 \times 19$ wire rope sample.
Etchant:
Glyceregia
X 250 


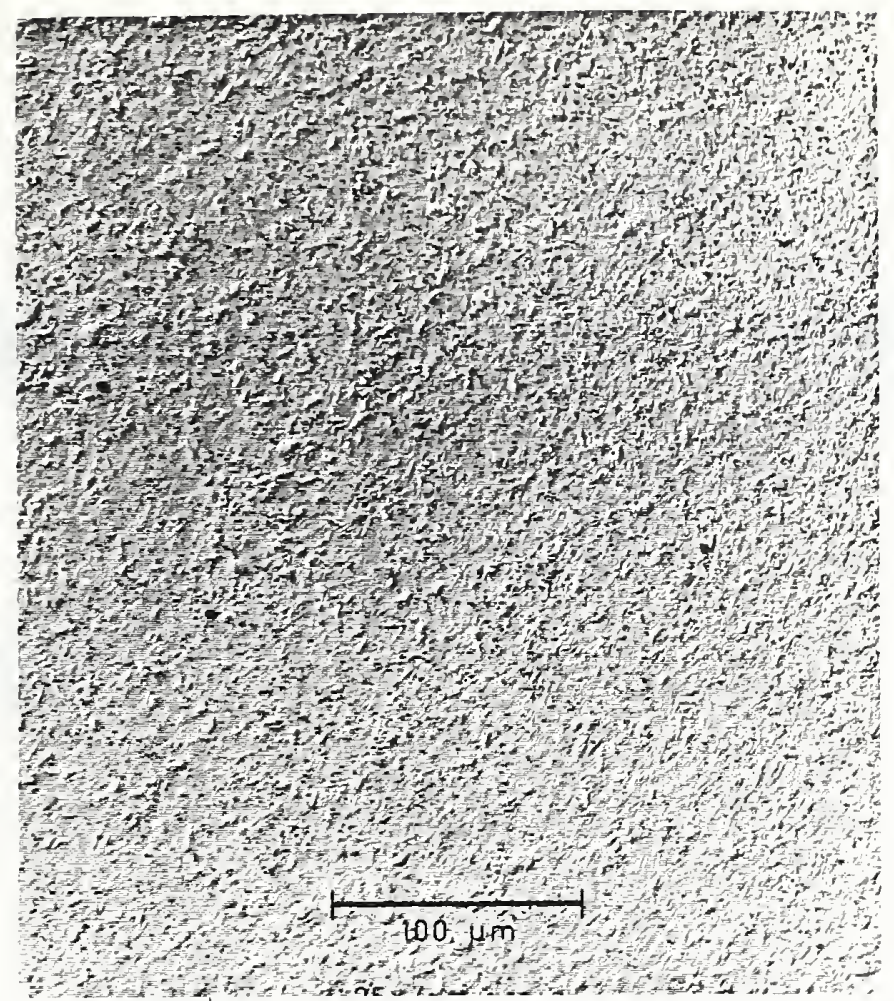

Figure 5. Representative microstructure of the center wire of the independent wire rope center of the $6 \times 7$ wire rope.

Etchant: Glyceregia

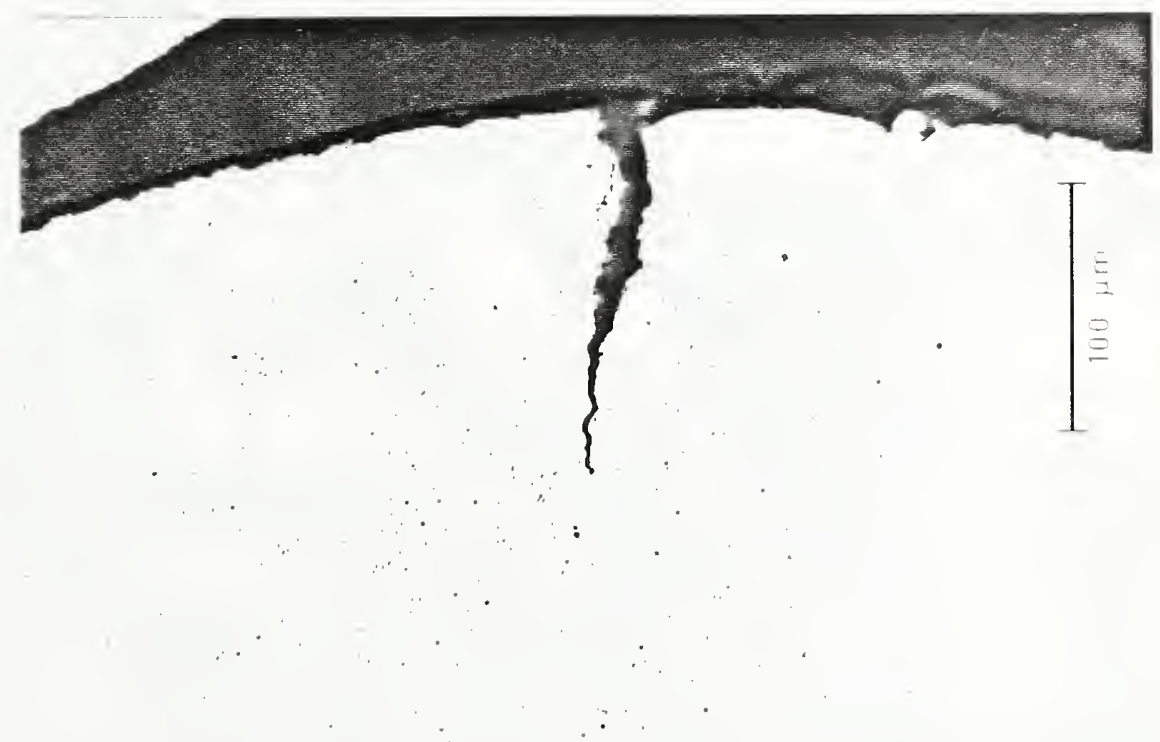

Figure 6. Longitudinal section through a wire from the $6 \times 19$ wire rope showing apparent lap seam. Etchant: Glyceregia 




Figure 7. Longitudinal specimen through a wire from a strand of the $6 \times 19$ wire rope different from the strand. containing the wire shown in figure 6 .
Etchant:
Glyceregia
X 250

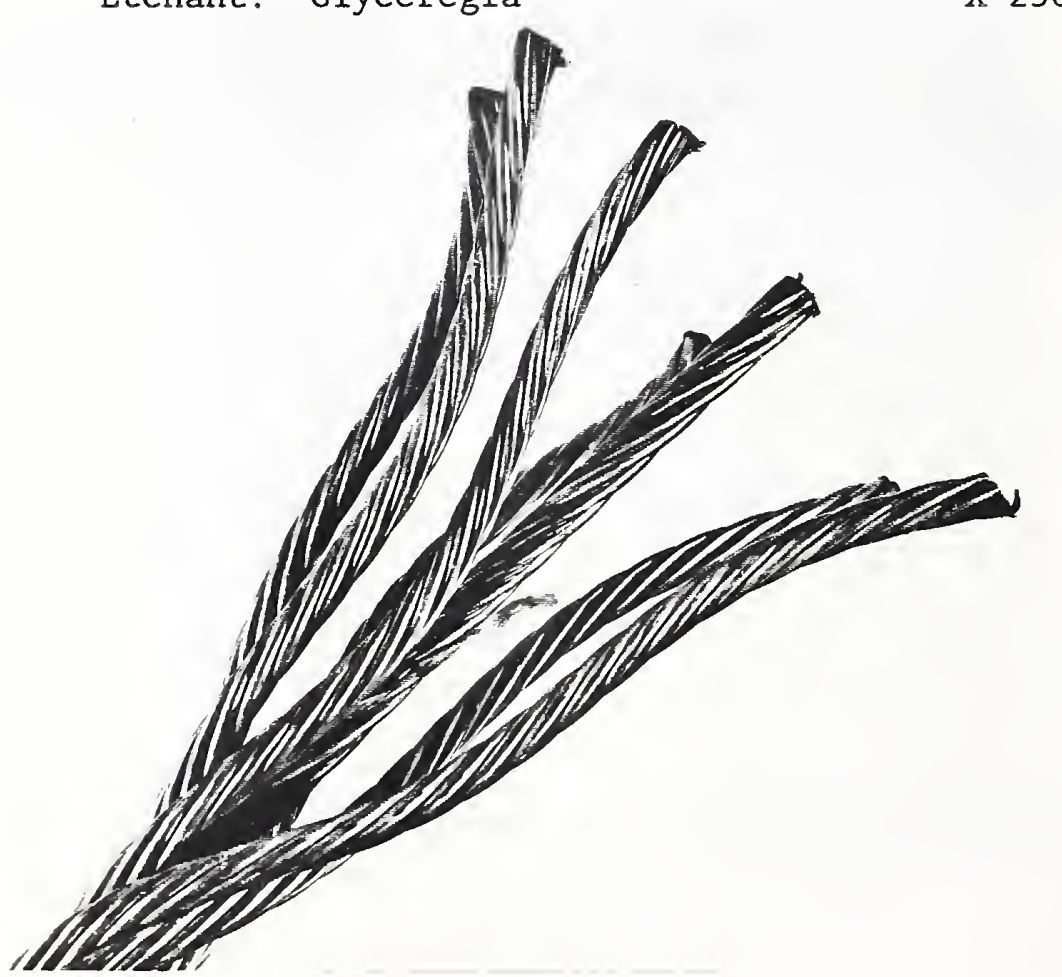

Figure 8. Broomed end of a specimen of the $6 \times 7$ wire rope. 




Figure 9. Terminal configuration for tensile tests (scale in inches).


Figure 10. Specimen set up for testing in tensile
testing machine. 


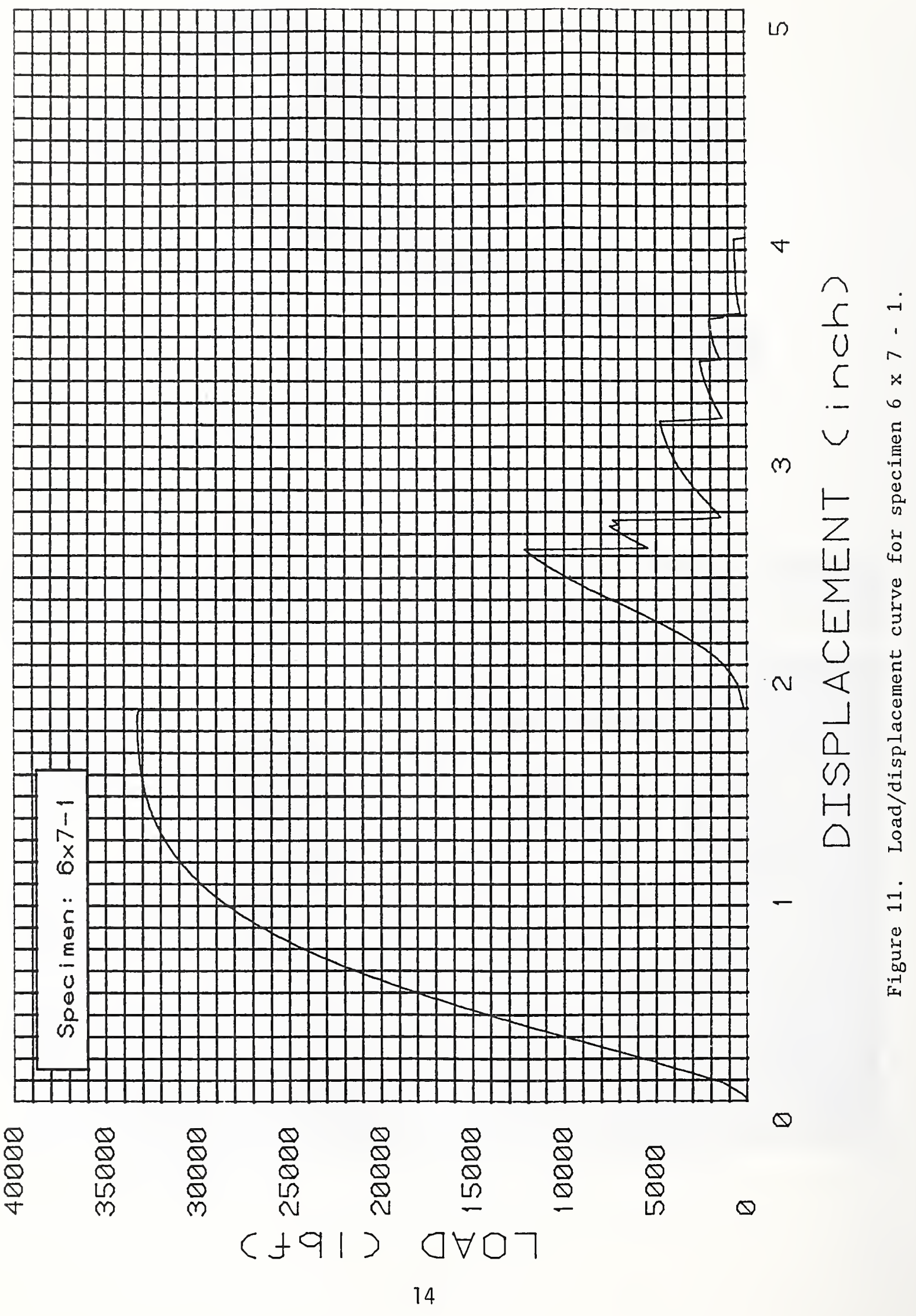




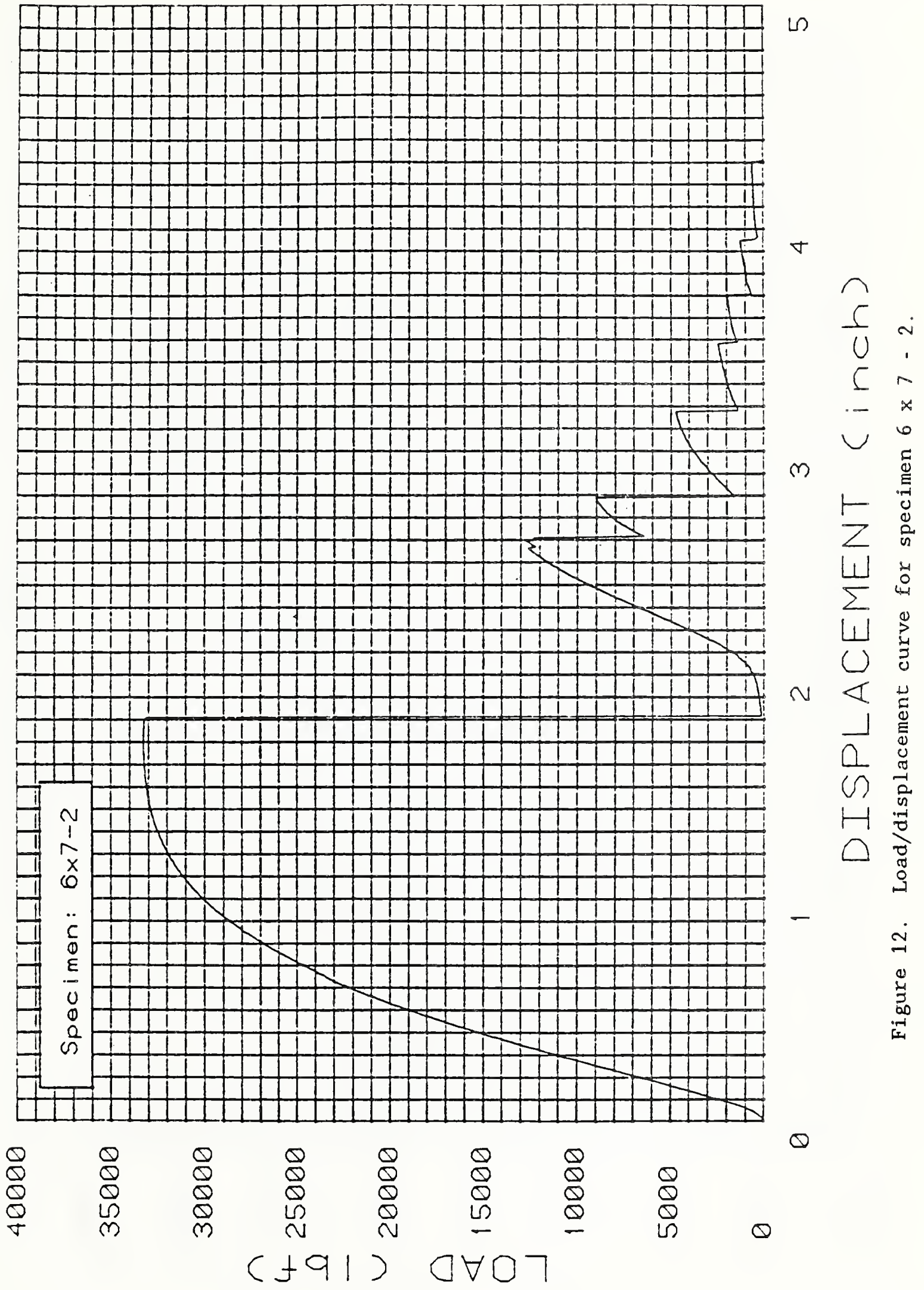









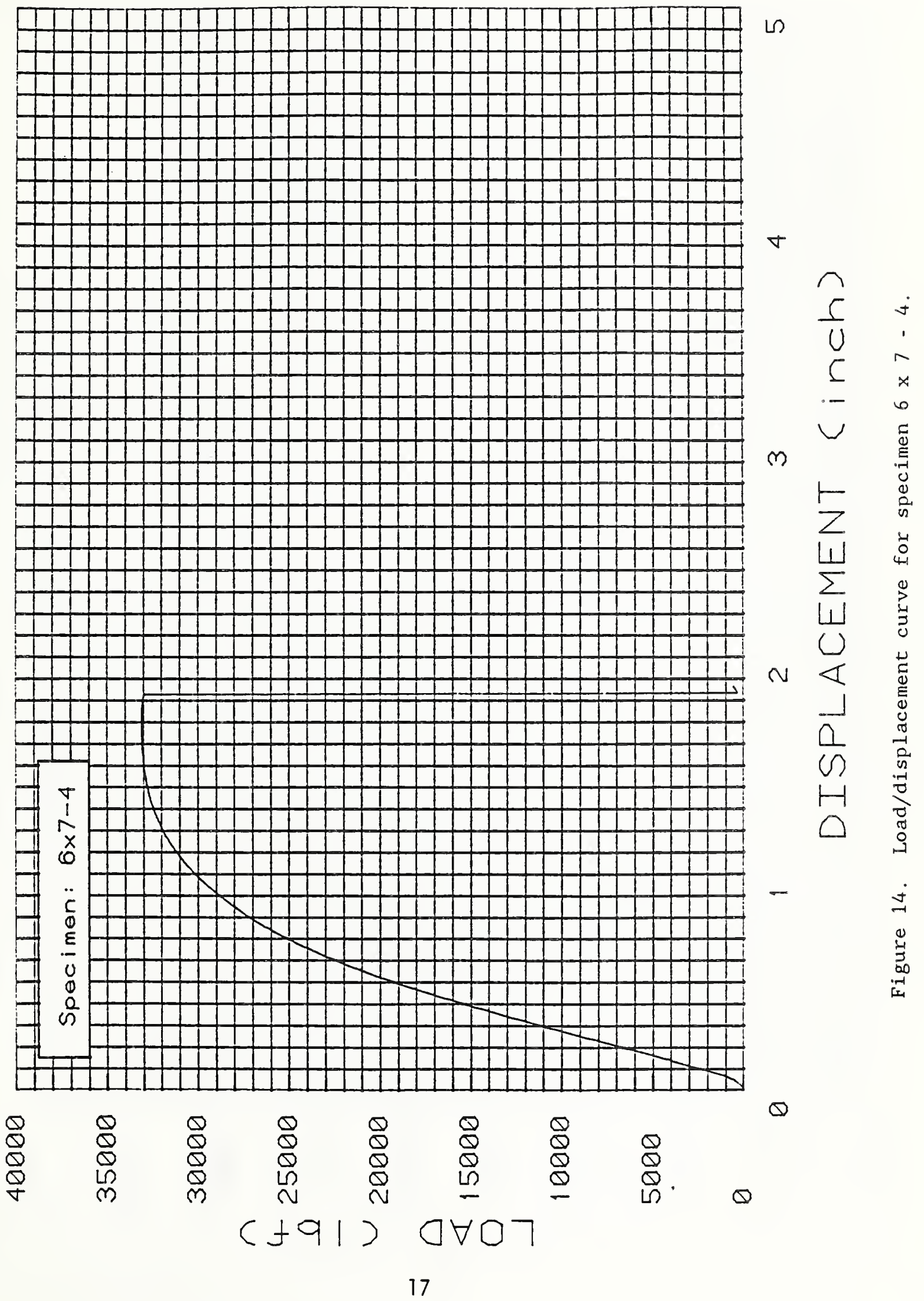




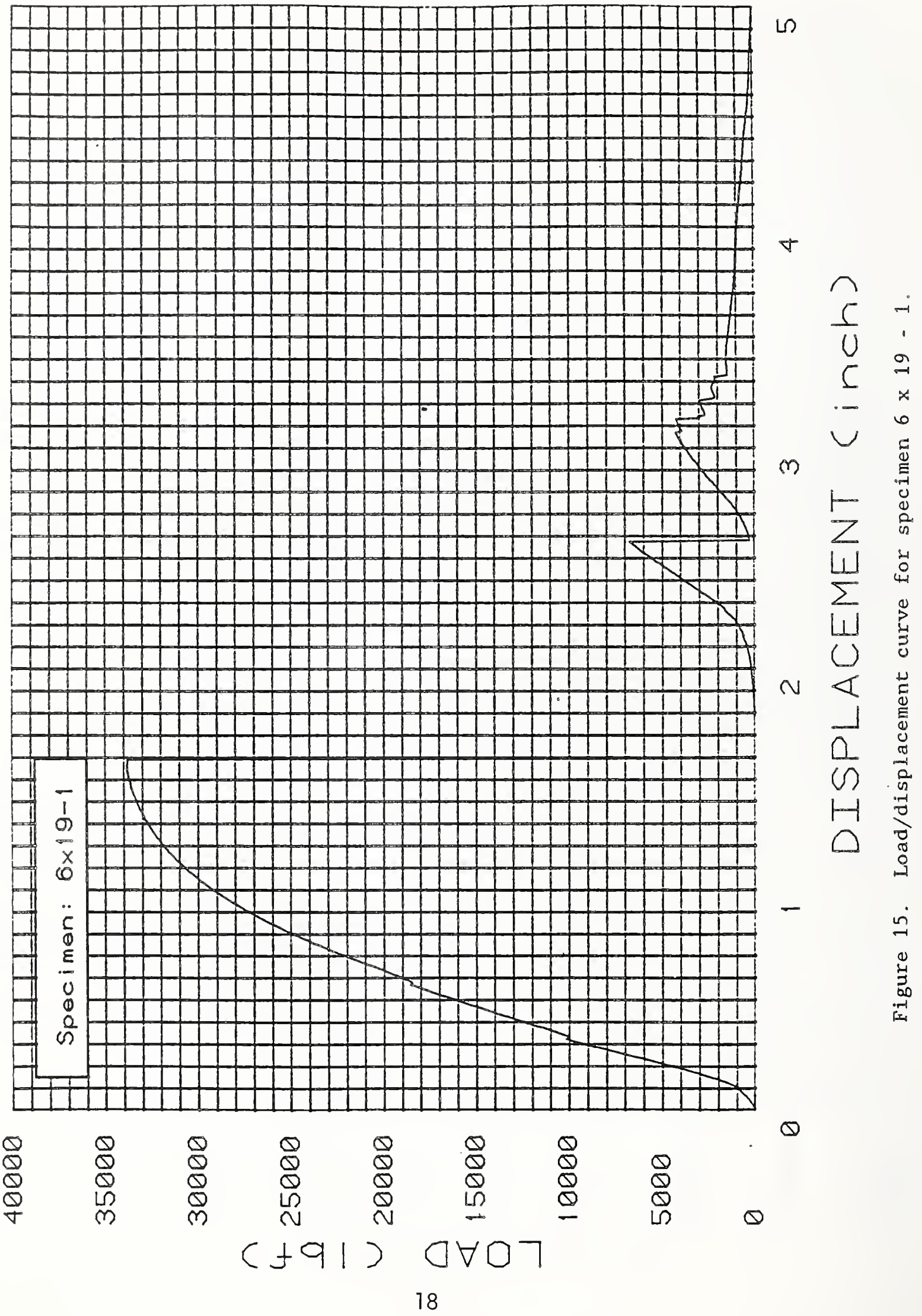




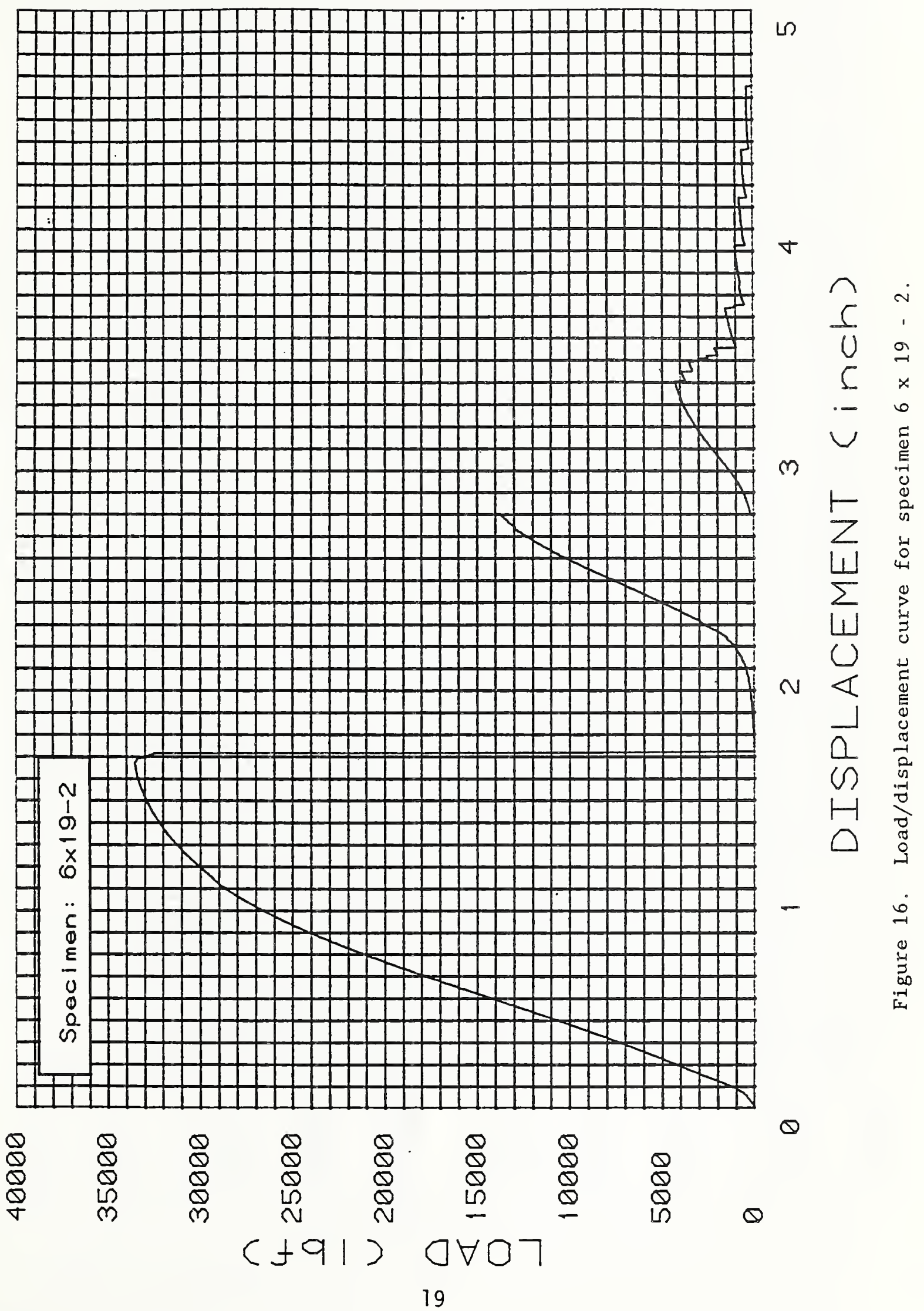




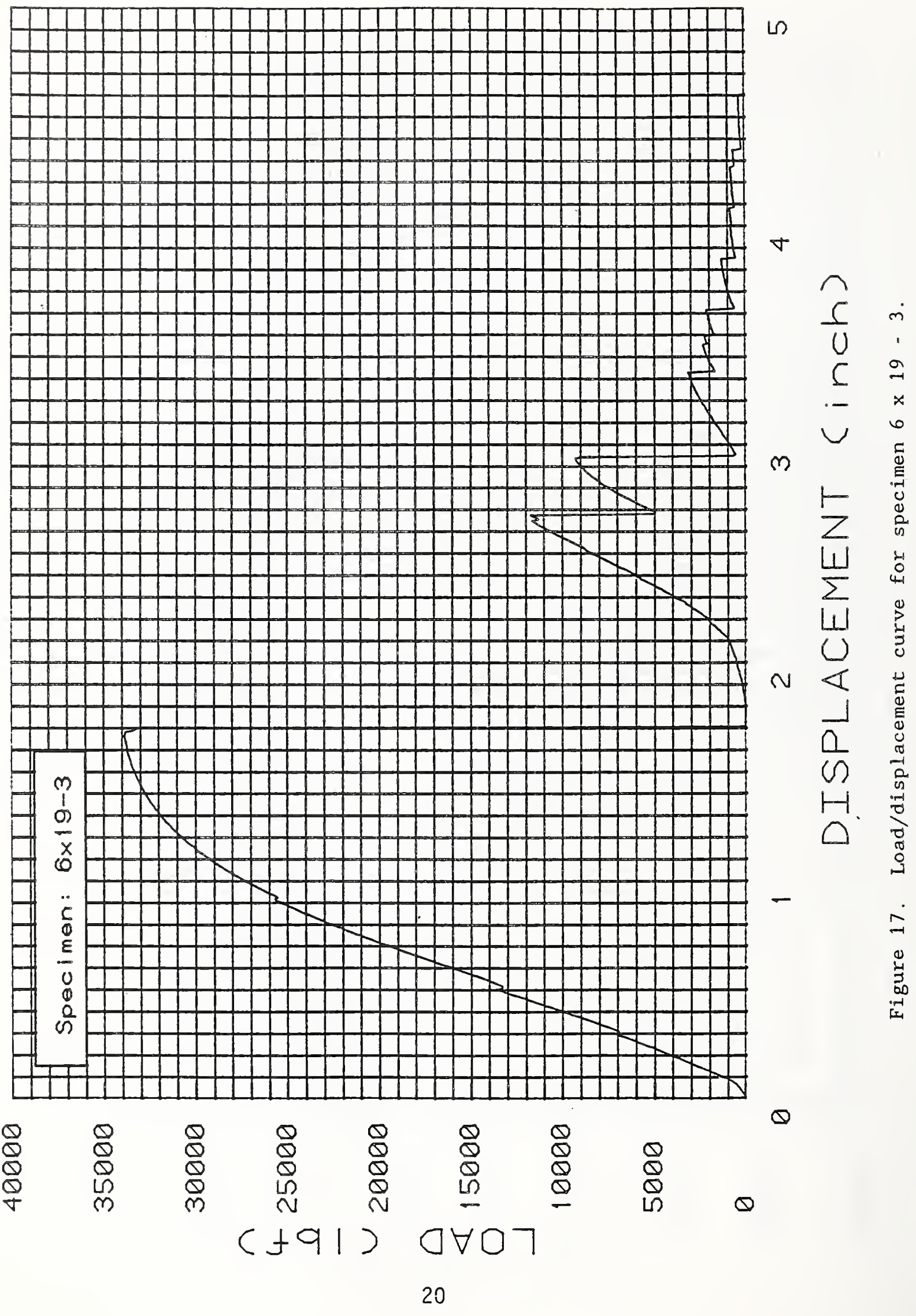




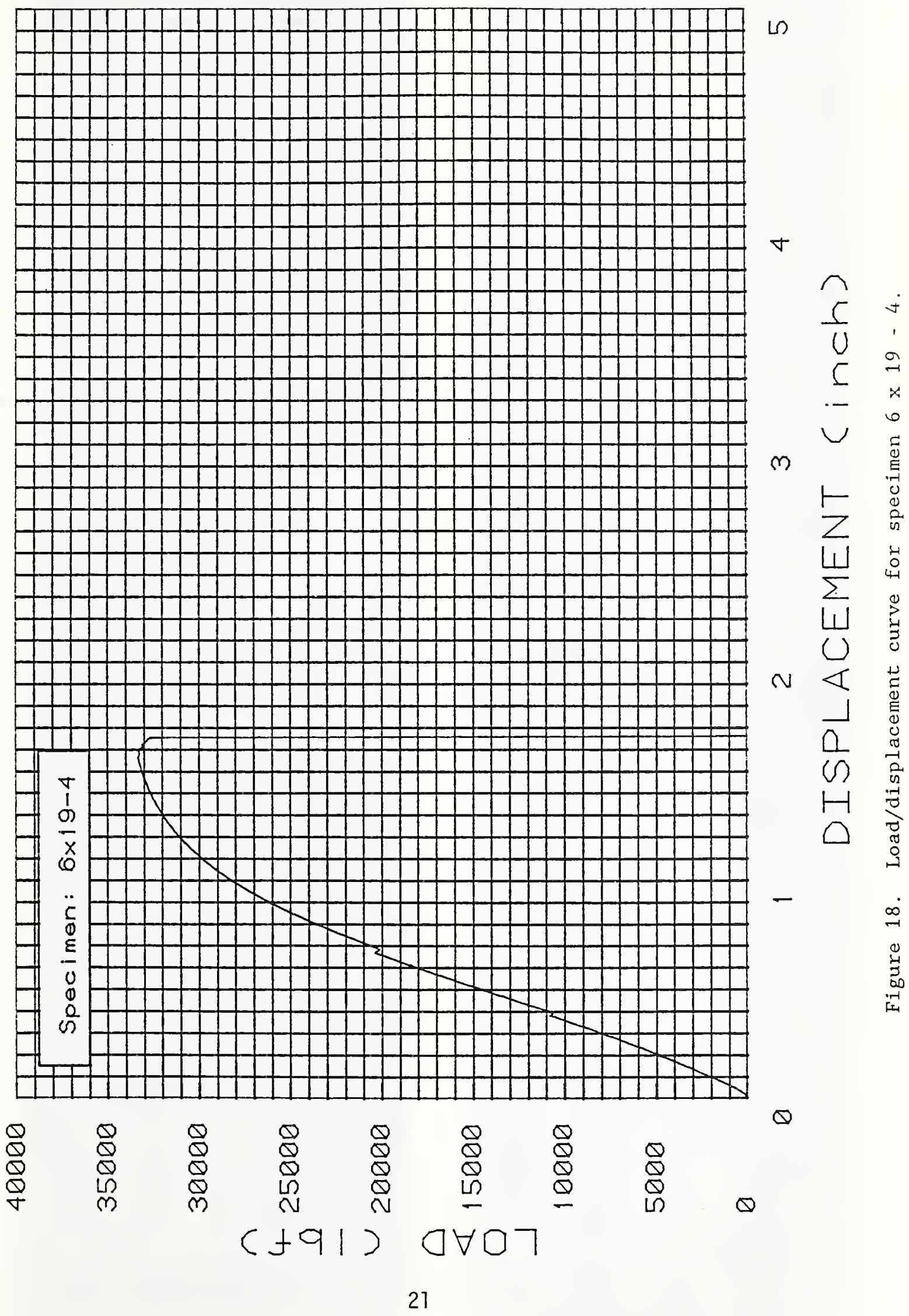



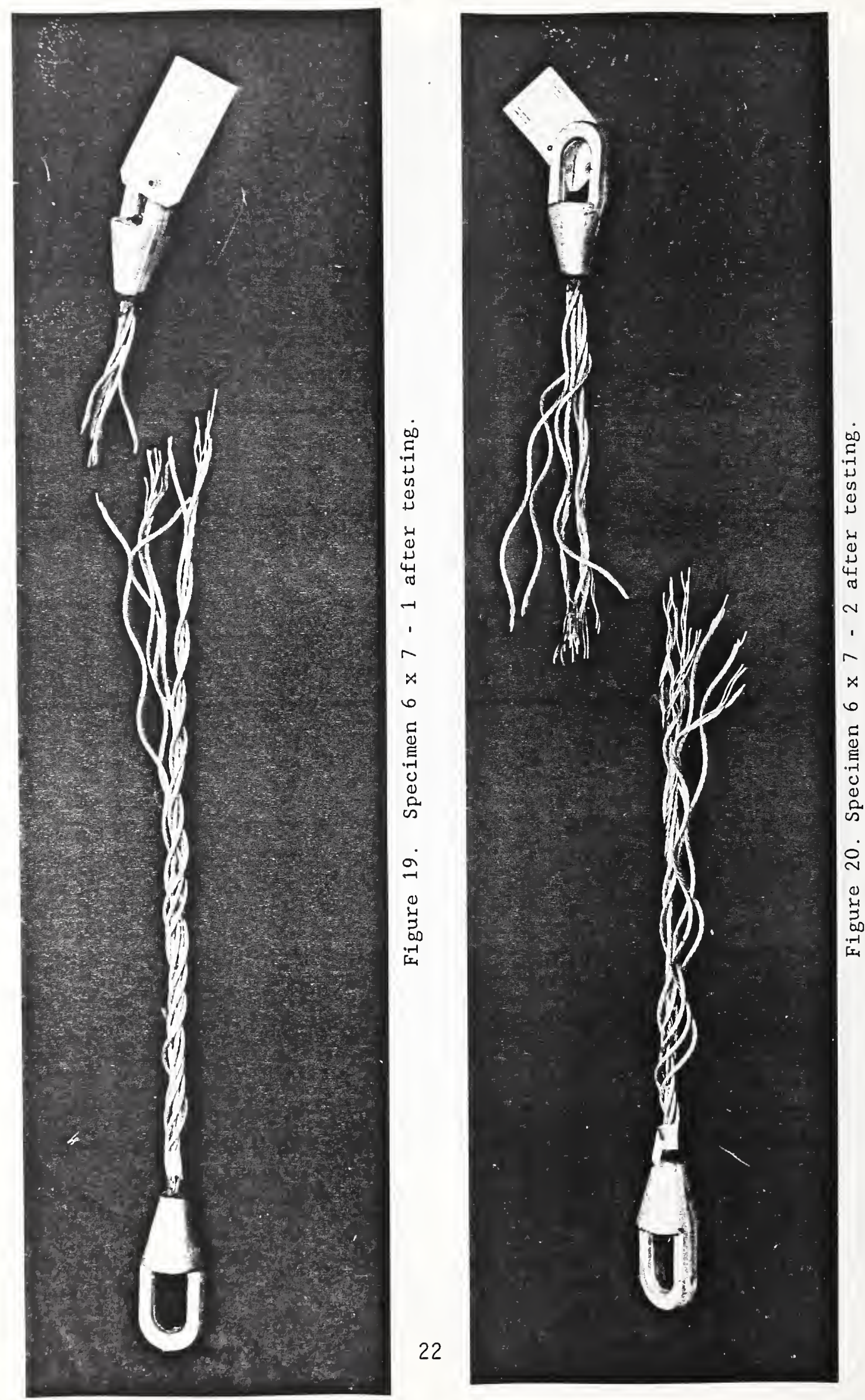



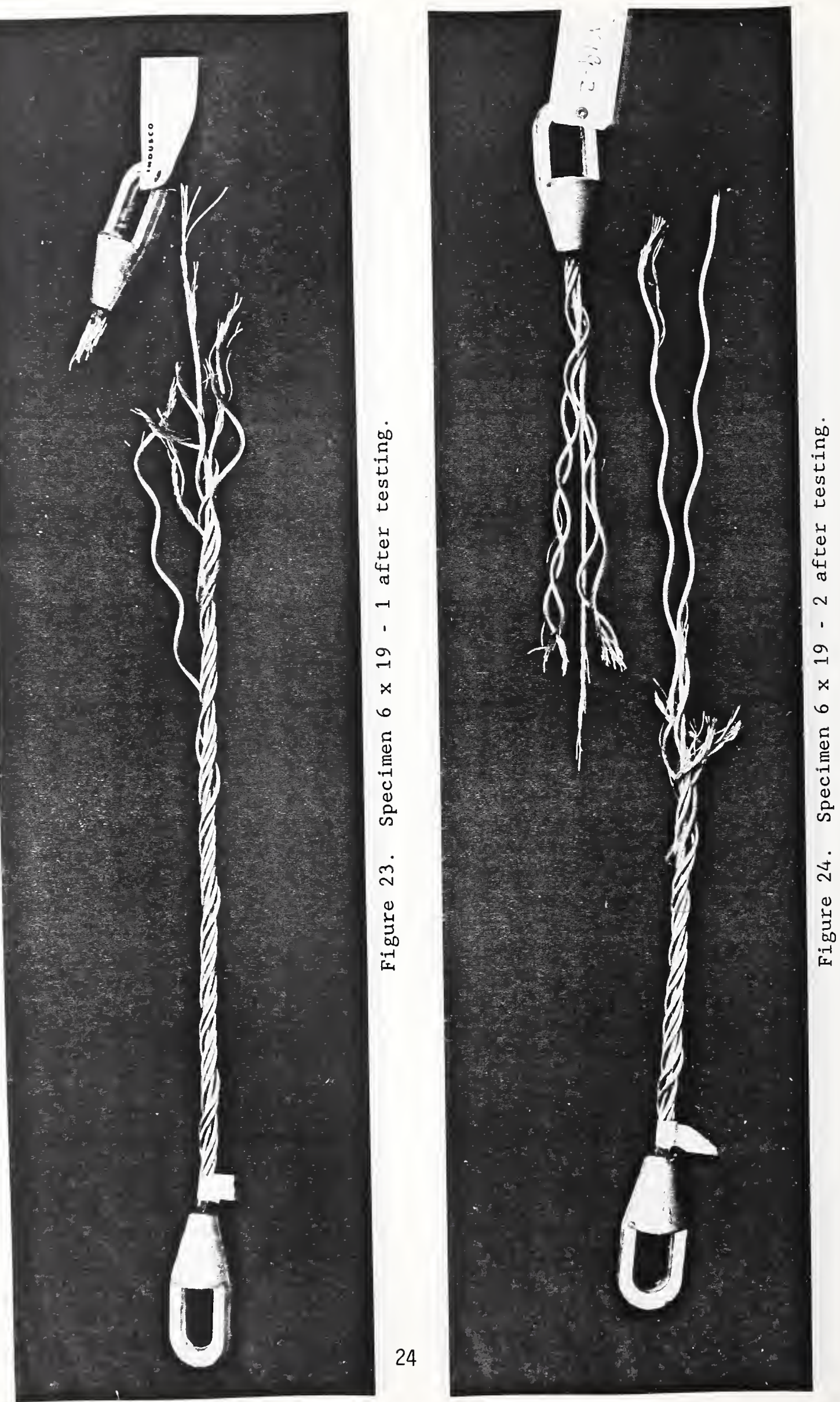


N8S-114A (REV. 208C)

U.S. DEPT. OF COMM.

BIBLIOGRAPHIC DATA

SHEET (See in structions)

4. TITLE AND SUBTITLE

1. PUBLICATION OR

REPORT NO.

NISTIR $89-4174$

TENSILE TESTS OF TYPE 305 STAINLESS STEEL MINE SWEEPING WIRE ROPE

5. AUTHOR(S)

T. Robert Shives and Samuel R. Low III

6. PERFORMING ORGANIZATION (If joint or other than NBS, see instructions)

7. ContractGrant No.

NATIONAL BUREAU OF STANDARDS

U.S. DEPARTMENT OF COMMERCE

GAITHERSBURG, MD 20899

9. SPCNSOAING ORGANIZATICN NAME ANC COMPLETE ADDRESS (Street, CIIY, StOTe, ZIF)

8. Type of Report \& Period Covered

10. SUPPLEMENTARY NOTES

$\square$ Document describes a computer program; SF-185, FIPS Software Summary, is attached.

11. ABSTRACT (A 200-word or less foctual summory of most significant information. If document includes a significant bibliogrophy or literoture survey, mention it here)

The tensile tests described in this report were performed by the Metallurgy Division of the National Institute of Standards and Technology (NIST) at the request of the Naval Coastal Systems Center, Panama City, Florida.

The Naval Coastal Systems Center submitted to NIST approximately 360 feet of each of two different AISI 305 stainless steel wire ropes for testing. Both wire ropes were nominally $5 / 8$ inch in diameter. One was stated as having a $6 \times 19$ configuration and the other a $7 \times 7$ configuration. The first number in such a designation indicates the number of strands in the wire rope and the second number indicates how many wires there are per strand.- For example, the wire rope with a $6 \times 19$ configuration consists of six strands of 19 wires each. As shown later, the wire rope stated to have a $7 \times 7$ configuration actually had a $6 \times 7$ configuration with an independent wire rope core (IWRC). The core is one of the three basic parts of a wire rope. The other two are the wires and the strands. The core may be comprised of steel or fiber. In the case of both of the submitted wire rope samples, the core consisted of an independent wire rope.

12. KEY WORDS (Six to twelve entries; alphobetical order; copitalize only proper nomes; and seporate key words by semicolons) Independent wire rope core, stainless steel wire rope, tensile test, wire rope

13. AVAILABILITY

X. Unlimited

$\square$ For Official Distribution. Do Not Release to NTIS

$\square$ Order From Superintendent of Documents, U.S. Government Printing Office, Washington. D.C. 20402.

Z Order From National Technical Information Service (NTIS), Springfield, VA. 2216I
14. NO. OF

PRINTED PAGES

27

15. Price

$\mathrm{AO} 3$ 

